\title{
Leaf nutritive value related to tiller development in warm- season grasses
}

\author{
J.R. HENDRICKSON, L.E. MOSER, K.J. MOORE, AND S.S. WAILER
}

Authors are forage agronomist, Northern Great Plains Research Laboratory, USDA-ARS, Mandan, N.D. 58554; professor, Department of Agronomy, University of Nebraska, Lincoln, Nebr. 68583; professor Department of Agronomy, Iowa State University, Ames, Iowa 50011, and assistant dean Agricultural Research Division, Institue of Agricultural and Natural Resources, Lincoln, Nebr. 68583. At the time of the research, the senior author was research assistant, Department of Agronomy, University of Nebraska, Lincoln, Nebr.

\begin{abstract}
Assessing nutritive value of key grass species in relation to plant development is essential for producers to efficiently manage livestock enterprises. Changes in nutritive value for tiller populations of 2 common Nebraska Sandhills grasses, prairie sandreed [Calamovilfa longifolia (Hook.) Scribn.] and sand bluestem [Andropogon gerardii var. paucipilus (Nash) Fern.], in response to morphological development was evaluated at the Gudmundsen Sandhills Laboratory (GSL) during the 1990 and 1991 growing seasons. Morphological development was determined on a 40 to 60-tiller sample from each block (12 blocks in 1990 and 8 blocks in 1991) at ten-day intervals using a comprehensive staging system. In vitro dry matter digestibility (IVDMD), crude protein (CP), neutral detergent fiber (NDF) and lignin were determined for leaves and correlated with the morphological index (Mean Stage by Count), growing degree days and day of the year. Leaf NDF values of both species remained constant while leaf IVDMD declined throughout the summer indicating that decline in leaf IVDMD was caused by declining cell wall digestibility. Leaf IVDMD was influenced more by tissue aging than advancing morphological stage. Leaf CP was significantly different between years but not between species indicating leaf CP was largely influenced by environmental factors. In both species and for both years, leaf $\mathrm{CP}$ initially declined rapidly to low levels and then stabilized during the vegetative phase. Nutritive value of a single vegetative morphological stage over the growing season was similar to the leaf tissue of the tiller populations. Management decisions by producers depend on accurate assessment of changes in nutritive value during the growing season in tiller populations of these 2 important grasses.
\end{abstract}

Key Words: Calamovilfa longifolia (Hook.)Scribn., Andropogon gerardii var. paucipilus (Nash) Fern., Phenology, IVDMD, Protein, populations.

Low nutritive value of grasses, especially $\mathrm{C}_{4}$ species, late in the growing season frequently limits animal production. Indicators of nutritive value including crude protein $(\mathrm{CP})$ and in vitro dry matter digestibility (IVDMD) generally decline in grasses as the growing season progresses (Anderson 1985, Undersander and

\footnotetext{
Published as journal article 11068 , Agr. Res. Div. University of Nebraska.

The authors would like to thank Drs. D. Briske, R. Lyons, K. Vogel, and W. Schach for their suggestions on earlier versions of the manuscript

Manuscript accepted 21 Apr. 1996
}

Hutchenson 1984, Perry and Baltensperger 1979). Increases in the proportion of stem tissue with maturity was a major determinate of whole-plant nutritive value in big bluestem (Andropogon gerardii Vitman) and switchgrass (Panicum virgatum L.) (Griffin and Jung 1983, Äman and Lindgren 1983). However, IVDMD values between leaves and stems of big bluestem and indiangrass [Sorghastrum nutans (L.) Nash] were comparable when sampled at the same date (Perry and Baltensperger 1979) indicating leaf maturation, rather than plant development, had the greatest influence on nutritive value.

Environmental variables are also known to affect nutritive value in addition to tissue age and plant development. Switchgrass leaves that developed earlier in the season during cooler temperatures had lower neutral detergent fiber (NDF) than leaves at the same growth stage developed later (Anderson 1985). High temperatures and low soil moisture reduced the nutritive value of Cynodon and Paspalum spp. (Henderson and Robinson 1982a, 1982b). Plant tissues produced in more extreme environmental stresses may result in lower nutritive value regardless of tissue age or stage of plant development.

Limited understanding of processes controlling nutritive value also interfere with our ability to define the relationship between nutritive value and plant development. Values for IVDMD decreased and NDF increased linearly for smooth bromegrass (Bromus inermis Leyss.) and timothy (Phleum pratense L.) (Sanderson and Wedin 1989) with advancing morphological development based on a staging system developed by Simon and Park (1983). However, IVDMD and CP values were more closely related to calendar day than morphological development in orchardgrass (Dactylis glomerata L.), smooth bromegrass, reed canarygrass (Phalaris arundinacea L.) and tall fescuc (Festuca arundinacea Schreb.) (Buxton and Marten 1989). Inconsistent predictions of nutritive value indicate that additional insight into the mechanism controlling nutritive value is required.

Previous researchers, attempting to relate morphological development of grasses to nutritive value, have often used indices that evaluate a small number of tillers rather than tiller populations. Tiller population estimates provide a more representative forage sample and may more accurately describe the morphology of the available forage. Moore et al. (1991) developed a system of growth staging that measured tiller populations rather than individual tillers or a selected group of tillers, that would effectively meet this requirement. 
The objectives of our study were to: 1) correlate changes in leaf nutritive value in response to morphological development on a tiller population basis for 2 Nebraska Sandhills grasses, prairie sandreed [Calamovilfa longifolia (Hook.) Scribn.] and sand bluestem [Andropogon gerardii var. palıcipilus (Nash) Fern.], using the growth staging system developed by Moore et al. (1991) and 2) estimate the importance of factors other than plant morphology on nutritive value by analyzing a single morphological stage. Both of these grasses are major components of the vegetation of the region and are heavily utilized by grazers (Northup 1993).

\section{Material and Methods}

\section{Field Procedures}

Nutritive value of prairie sandreed and sand bluestem was evaluated for 2 years under range conditions. The study took place at the Gudmundsen Sandhills Laboratory (GSL) near Whitman in the Nebraska Sandhills. Soils were Valentine fine sands (mixed, mesic, typic Ustipsamments) and the vegetation was dominated by prairie sandreed and sand bluestem. A mixture of forbs and other grasses, including little bluestem [Schizachyrium scoparium (Michx.) Nash], prairie junegrass [Koelaria macrantha (Ledeb.) Schult.] and switchgrass, comprised the remaining vegetation. Sample locations were in good range condition. Average annual precipitation is $514 \mathrm{~mm}$ and falls mainly during the growing season (May-September). During the 1990 sampling period of May through August, precipitation was $251 \mathrm{~mm}$ or $76 \%$ of normal. During the same period in 1991, precipitation was $353 \mathrm{~mm}$ or $110 \%$ of normal. Valentine fine sands have a low water-holding capacity which makes precipitation frequency more important than total amount for plant growth. Although 1990 was drier than 1991, 1990 had smaller but more frequent rains throughout the growing season. Weather data were collected electronically at GSL headquarters approximately 1 to $2 \mathrm{~km}$ from the plots. Thirty-year averages were taken from a U.S. Weather Bureau station located $20 \mathrm{~km}$ northeast of the field site.

In April 1990, 12 blocks, ranging from $20 \times 20 \mathrm{~m}$ to $30 \times 50 \mathrm{~m}$, were located within a $2 \mathrm{~km}$ radius. Block size was determined by plant composition and terrain homogeneity. All blocks were located on sands range sites where grazing had ended before sampling. In April 1991, 8 blocks, comparable to the 1990 blocks, were located within the same $2 \mathrm{~km}$ radius. Sampling of prairie sandreed began on 15 May in 1990; however, sand bluestem was not sampled until 31 May 1990 because of limited plant growth. Sampling then continued at 10-day intervals until 24 August 1990. In 1991, sampling of both species started 20 May and continued until 21 August at similar intervals to 1990 .

Twelve transects were permanently marked within each block at the start of each season to aid in sample location. Transect length varied with block size. Samples for evaluating morphological development were located by randomly selecting a transect and a random point along the transect. A corner of a $1-\mathrm{m}^{2}$ quadrat was placed on the random point and all tillers of either sand bluestem or prairie sandreed were clipped at $3 \mathrm{~cm}$. This procedure was repeated, within a block, until a sufficient number of tillers (40-60) was collected. Complete quadrats were clipped even if the minimum tiller number was reached prior to completion of clipping to avoid bias in harvesting tillers. After a quadrat was harvested, the area was marked with a flag to prevent resampling. This procedure was then repeated for the other target species. Both species were sampled in this manner in all blocks at all dates. The sampling regime was repeated in the second year, although in 1991, a minimum of 2 quadrats was harvested even if the minimum tiller number was reached in the first quadrat. Because of the variable number of quadrats needed to reach the minimum quadrat and tiller numbers for earh species, not all the transects wcre sampled on each harvest date. Five to 10 transects were usually sampled within each block during each harvest.

While the samples used to classify growth stage were being collected, separate samples of each species were collected for nutritive value analysis from quadrats randomized as described above. This sampling was continued until at least $20 \mathrm{~g}$ (fresh weight) of material was collected. On harvests $1,3,5,7$, and 9, additional sampling of prairie sandreed was conducted in the same manner until about $20 \mathrm{~g}$ (fresh weight) of tillers in the 3-leaf vegetative stage (V3) was collected for nutritive value analysis. On harvests $2,4,6,8$, and 10 , additional sampling of the V3 stage of sand bluestem was conducted. The V3 stage was the smallest stage that appeared throughout the growing season in sufficient quantities for analyzing nutritive value. All samples were dried in a forced air oven at $55^{\circ} \mathrm{C}$ for 4 days.

Sheaths were retained with leaves until stem development could be detected. Stems were identified by the presence of palpable nodes. All tillers were dried and if stem material was present the leaf blades were removed at the collar and sheaths were included in the stem portion. All material above the last node was considered leaf tissue. After head emergence, the heads were included with the stems. All quality samples were ground to pass through a $1-m m$ screen.

\section{Field Classification}

Determining the morphological development of the tiller populations was accomplished using the mnemonic scale described in Moore et al. (1991). This system divides the life cycle of individual grass tillers into 5 primary growth stages with the following index values: 0) germination, 1) vegetative, 2) elongation, 3) reproductive, and 4) seed ripening, but the germination growth stage was not applicable in our study. Fach primary stage contains substages describing specific events that occur in most grasses. Each harvested tiller was assigned a mnemonic stage in the field and placed in a sack with tillers of the same species and mnemonic stage. The number of tillers in each stage were counted and each separate stage was dried at $55^{\circ} \mathrm{C}$ before weighing.

Assigning quantitative indices (Moore et al. 1991) was completed at the end of the growing season. The mean stage by count (MSC) is a numerical weighted average using all the tillers from each stage within a sample location. It was calculated for each species using the following formula:

$$
\text { Mean Stage by Count (MSC) }=\sum_{\mathrm{i}=0}^{4.9} \frac{\mathrm{S}_{\mathrm{i}} \mathrm{N}_{\mathrm{i}}}{\mathrm{C}}
$$

Where: $S_{i}=$ growth stage, 1 to 4.9

$\mathrm{N}_{\mathrm{i}}=$ number of tillers in stage $S_{\mathrm{i}}$

$\mathrm{C}=$ total number of tillers 
The value for mean stage by weight (MSW) was calculated by replacing $\mathrm{N}$ with the dry weight of tillers in stage $S_{i}$ and $C$ with the total dry weight of all the tillers. Both indices are the weighted average of all stages using the tiller count (MSC) or tiller weight (MSW) in each substage. This procedure quantifies morphological development of the tiller population and is reported as a decimal value of a primary growth stage. A higher MSC or MSW value indicates a more morphologically advanced tiller population. For example, a tiller population with a MSC value of 1.5 is primarily vegetative but more advanced than a population with a MSC value of 1.2 .

\section{Laboratory Procedures}

Neutral detergent fiber and permanganate lignin were determined on the composite samples according to Goering and Van Soest (1970). Crude protein content was estimated on a dry matter basis from Kjeldahl $\mathrm{N} \times 6.25$ (A.O.A.C. 1976). In vitro dry matter digestibility was estimated using a 2-stage procedure with urea in the buffer (Marten and Barnes 1980). Crude protein and IVDMD were also determined on the individual growth stage (V3). Samples were dried for 12 hours at $50^{\circ} \mathrm{C}$ in a forced air oven before weighing for laboratory procedures and all values are based on oven-dry weights.

The data were analyzed as a split-plot with species being the main plot effect and harvest date being the sub-plot. Blocks were used as replications and transects were averaged within each block. Correlation analysis was conducted using only the harvest means. Data were analyzed using GLM (SAS 1985).

\section{Results and Discussion}

In both species, the morphological indices of mean stage by count and mean stage by weight were highly correlated within both years $(r=0.99)$ so results are presented using only the mean stage by count index. The mean stage by count index is faster and easier to use in the field. Tiller populations of both species remained predominately vegetative (mean stage by count 1.0 to 2.0) throughout most of the study period in both years and only the mean stage by count of prairie sandreed in 1991 advanced past the early elongation stage. Lack of morphological advancement in the tiller populations may have occurred because of large numbers of young emerging tillers. A high proportion of immature tillers would have retarded advancement to later growth stages by weighting morphological development to a lower mean stage by count. However, tiller populations contained up to 20 separate morphological stages at the end of the growing season. A majority of the observed changes in nutritive value occurred while both species populations were primarily in the vegetative stage. Since grazing livestock generally utilize grass leaves more than stems even in mature tillers (Kirby and Stuth 1982, Minson 1990, Stuth 1991), changes in leaf nutritive value over the growing season were emphasized.

\section{Leaf Nutritive Value}

Leaf IVDMD was negatively correlated $(\mathrm{P}<0.05)$ with advances in morphological development of the tiller population (mean stage by count), growing degree days and day of the year
(Table 1); however, leaf NDF changed relatively little during the growing season (Fig. 1) and was not significantly correlated (P>0.05) with leaf IVDMD. Burzlaff (1971) reported leaf NDF of these species were unaffected by advancing maturity. The lack of correlation between NDF and IVDMD, along with the relative stability of leaf NDF over the growing season, indicated that leaf IVDMD in these 2 species was influenced more by changes in cell wall digestibility than a decline in the highly digestible cell contents.

\begin{tabular}{|c|c|c|c|c|c|}
\hline Species & Year & Variable & Lignin & IVDMD & $\mathrm{CP}$ \\
\hline \multirow[t]{3}{*}{ Sand Bluestem } & 1990 & DAY & 0.83 & -0.94 & -0.85 \\
\hline & & GDD & 0.83 & -0.94 & -0.84 \\
\hline & & MSC & 0.83 & -0.92 & -0.82 \\
\hline \multirow[t]{3}{*}{ Sand Bluestem } & 1991 & DAY & 0.31 & -0.94 & -0.90 \\
\hline & & GDD & 0.32 & -0.93 & -0.89 \\
\hline & & MSC & 0.35 & -0.95 & -0.90 \\
\hline \multirow[t]{3}{*}{ Prairie sandreed } & 1990 & DAY & 0.77 & -0.99 & -0.87 \\
\hline & & GDD & 0.79 & -0.99 & -0.85 \\
\hline & & MSC & 0.78 & -0.97 & -0.79 \\
\hline \multirow[t]{3}{*}{ Prairie sandreed } & 1991 & DAY & 0.29 & -0.96 & -0.91 \\
\hline & & GDD & 0.29 & -0.96 & -0.90 \\
\hline & & $\mathrm{MSC}$ & 0.23 & -0.93 & -0.85 \\
\hline
\end{tabular}

Reductions in cell wall digestibility have most commonly been associated with increasing lignin (Van Soest 1982). Leaf lignin values in 1990 had significant positive correlations $(\mathrm{P}<0.05)$ with mean stage by count, growing degree days and day of the year, but 1991 values were highly variable and not significantly correlated $(\mathrm{P}>0.05)$ with any of these variables (Table 1$)$. High temperatures have been shown to increase lignification (Van Soest et al. 1978, Henderson and Robinson 1982a). There were several periods in 1991 when temperatures fluctuated up to $15^{\circ} \mathrm{C}$ within a 1 or 2 day time period with high temperatures reaching $38^{\circ} \mathrm{C}$. These fluctuations may have increased variability in leaf lignin values. Changes in lignin composition rather than lignin concentration may be the determining factor in inhibiting cell wall digestibility (Jung 1989). Although leaf lignin concentrations were not highly correlated with leaf IVDMD, changes in lignin composition could influence IVDMD as the growing season progressed.

Although leaf IVDMD of both species was highly correlated with mean stage by count in both years, morphological advancement alone may not fully or accurately explain the decline in IVDMD. Advancing morphological development affects nutritive value by increasing the proportion of low quality stems in the available forage (Griffin and Jung 1983). In this study, IVDMD declined in leaf tissue alone. Also, tiller populations of both species were largely vegetative during both years (Fig. 2). When morphology was held constant by examining a single morphological stage (V3) both day of the year and growing degree days had significant negative correlations with IVDMD similar to the composite samples (Table 2). Lower leaf IVDMD may have been 

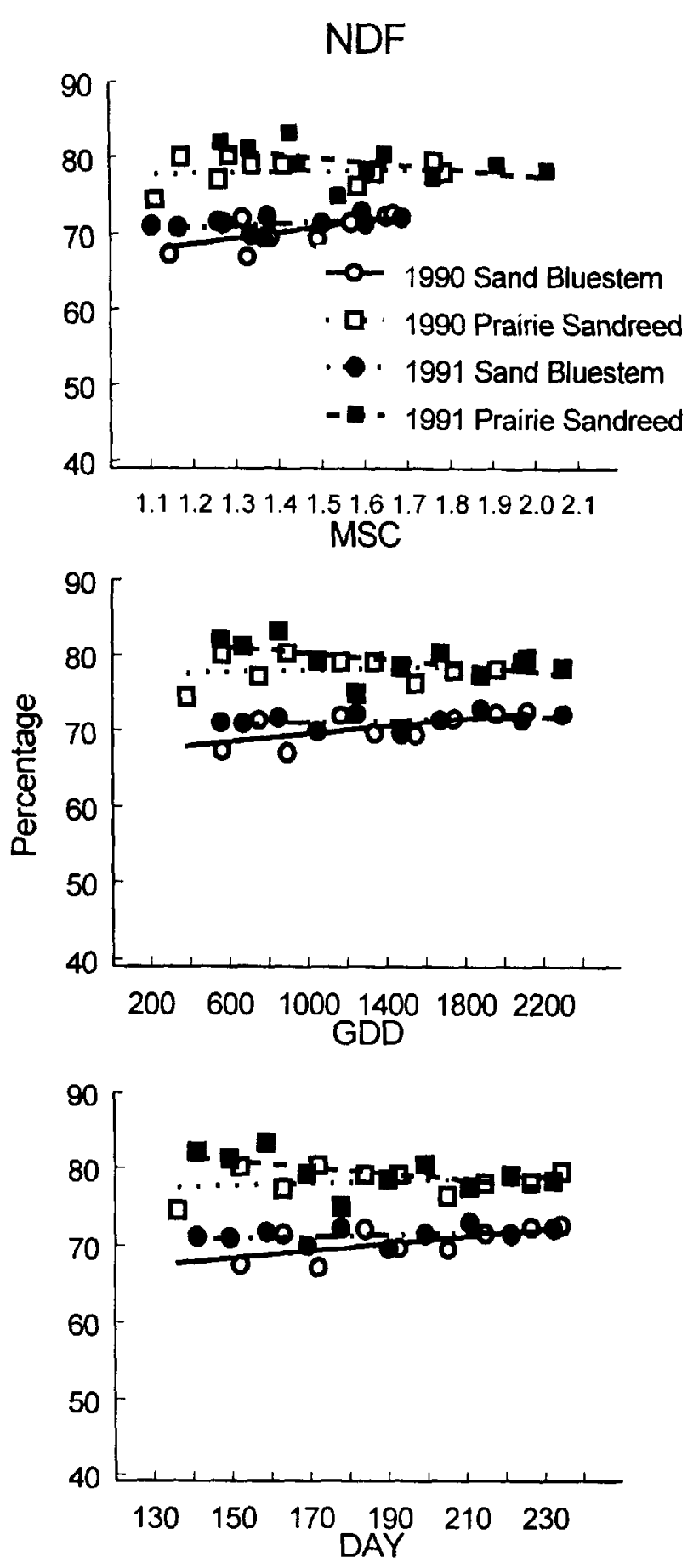

Fig. 1. Neutral detergent fiber (NDF) correlated with mean stage by count (MSC), growing degree days (GDD) and calendar day (DAY) for prairie sandreed and sand bluestem leaves in 1990 and 1991. The coefficients of variation (C.V.) are as follows; prairie sandreed 1990 C.V. $=1.96,1991$ C.V. $=1.75$, sand bluestem 1990 C.V. $=2.58,1991$ C.V. $=2.73$.

influenced by including sheath tissue with leaves in tillers that were in the vegetative stage. This lower quality tissue may have diluted the nutritive value of leaves as mean stage by count advanced.
Tissue maturity was more important than morphological development in detcrmining nutritive value of big bluestem and indiangrass (Perry and Baltensperger 1979). Tissue aging reduced cell wall digestibility in other $\mathrm{C}_{4}$ grasses (Anderson 1985). The strong negative correlation of leaf IVDMD to day of the year (Table 1) supports the conclusion that tissue aging may reduce cell wall digestibility. Exact aging of the tiller populations was not done in this study; however, a separate study (Hendrickson et al. unpublished data) inclicated most prairie sandreed tillers were initiated early in the growing season. Therefore, leaf IVDMD of prairie sandreed samples collected late in the growing season were probably from tillers that emerged early in the growing season.

Environmental conditions also affect nutritive value (Henderson and Robinson 1982a,1982b; Van Soest et al. 1978). The strong correlation $(\mathrm{P}<0.05)$ between growing degree days and leaf IVDMD indicates that temperature had some influence on nutritive value. However, factors that decrease plant growth have been correlated with increased nutritive value (Van Soest et al. 1978). Lower precipitation and cooler temperatures, along with retarded morphological development of prairie sandreed, indicated less favorable growing conditions in 1990 than in 1991, but leaf IVDMD was not significantly different between years $(P>0.05)$. Differences between years affected leaf CP more than IVDMD.

There were significant differences in leaf $\mathrm{CP}$ between years $(P<0.05)$ but not between species indicating that environmental variables were more important than species differences in influencing CP levels. Crude protein for both species in both years declined sharply early in the season and then stabilized (Fig. 3). Previous studies on these grasses in the same study site have shown a similar trend (Bredja per. com., Agronomy Dept., Univ. of Nebraska). In 1990, leaf CP decreased by approximately $50 \%$ in both species before the tiller populations had reached the middle of the vegetative stage (mean stage by count $=1.5$ ). The decline in leaf CP may have been caused by a combination of dilution with non-protein compounds and $\mathrm{N}$ translocation. Perennial grasses accumulate most of their $\mathrm{N}$ prior to the growing season (McKendrick et al. 1975) and the first leaves are usually high in CP. In sand bluestem, however, these leaves are smaller and shorter lived than later emerging leaves (Sims et al. 1973). The increased volume of the larger, later emerging leaves could dilute CP as the season progressed. In addition, leaf growth may continue as $N$ uptake declines (Heckatorn and DeLucia 1994) making the later emerging leaves lower in $\mathrm{N}$. As new leaves were

Table 2. Pearson correlation coefficients for in vitro dry matter digestibility (IVDMD) and crude protein (CP) correlated with growing degree day (GDD) and day of the year (DAY) for a single 3-leaf vegetative stage (V3) of prairie sandreed and sand bluestem in 1990 and 1991.

\begin{tabular}{lcccc}
\hline Species & Year & Variable & DAY & GDD \\
\hline Prairie Sandreed & 1990 & CP & -0.99 & -0.90 \\
& 1991 & CP & -0.99 & -0.90 \\
& $1990-1991$ & IVDMD & -0.96 & -0.98 \\
Sand Bluestem & 1990 & CP & -0.83 & -0.83 \\
& 1991 & CP & -0.88 & -0.88 \\
& $1990-1991$ & IVDMD & -0.96 & -0.98 \\
\hline
\end{tabular}




\section{IVDMD}
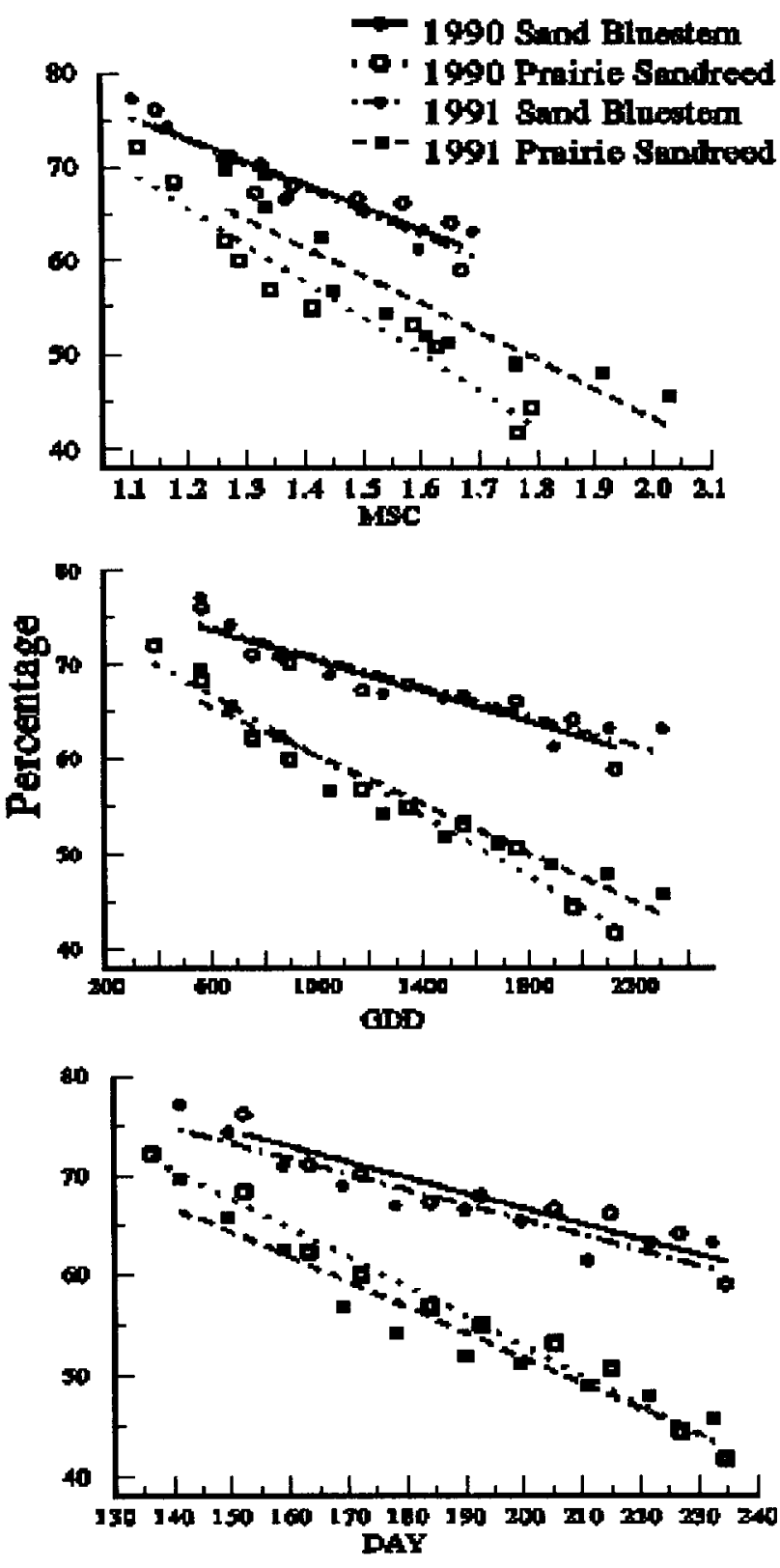

Fig. 2. In vitro dry matter digestibility (IVDMD) correlated with mean stage by count (MSC), growing degree days (GDD) and calendar day (DAY) for prairie sandreed and sand bluestem leaves in 1990 and 1991. The cuefficients of variation (C.V.) are as follows; prairie sandreed $1990 \mathrm{C} . \mathrm{V} .=5.07,1991 \mathrm{C} . \mathrm{V} .=4.53$, sand bluestem 1990 C.V. $=3.37,1991$ C.V. $=3.61$.

formed, $\mathrm{N}$ may have been translocated from the older leaves into the new leaves (Yoneyama 1977, Pate and Atkins 1983). Crude protein values would have stabilized when CP levels of new leaves were diluted by a larger quantity of low CP older leaves.

As $\mathrm{N}$ uptake declines, internal recycling of $\mathrm{N}$ may increase in importance. Translocation of $\mathrm{N}$ from aging leaves accounted for up to $100 \%$ of the $\mathrm{N}$ input in new leaves of cotton sedge
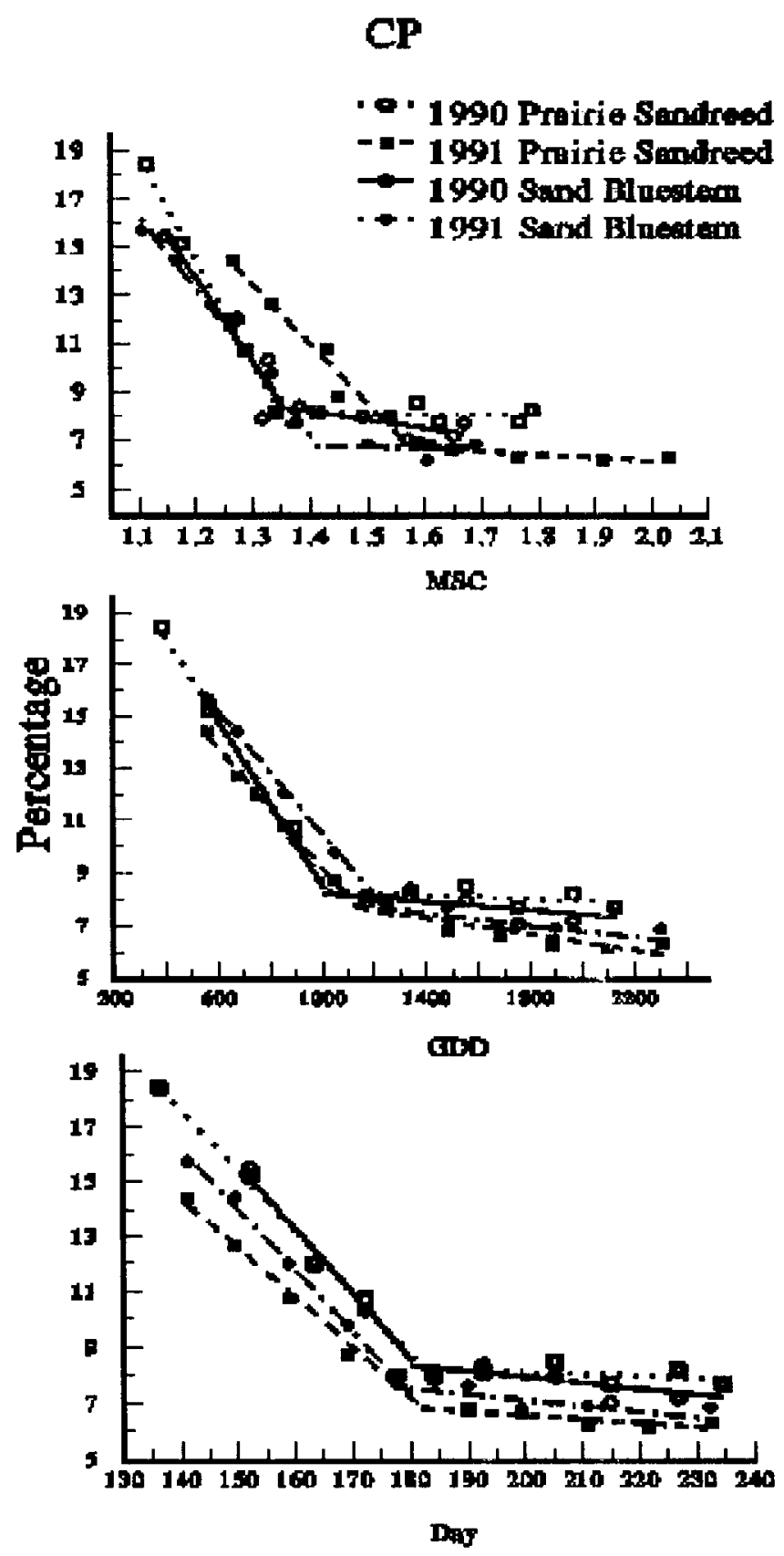

Fig. 3. Crude protein (CP) correlated with mean stage by count (MSC), growing degree days (GDD) and calendar day (DAY) for prairie sandreed and sand bluestem leaves in 1990 and 1991. The coefficients of variation (C.V.) are as follows; prairie sandreed $1990 \mathrm{C} . \mathrm{V} .=7.48,1991 \mathrm{C} . \mathrm{V} .=7.24$, sand bluestem $1990 \mathrm{C} . \mathrm{V} .=7.16$, 1991 C.V. 22.89.

(Eriphorum vaginatum L.) in an interior Alaskan site (Jonasson and Chapin 1985). They suggested that effective nutrient remobilization and sequential leaf development enables cotton sedge to minimize dependence on soil nutrients and thus dominate nutrient poor sites. Prairie sandreed and sand bluestem may also depend on internal translocation of nutrients in the nutrient poor Nebraska Sandhills. 


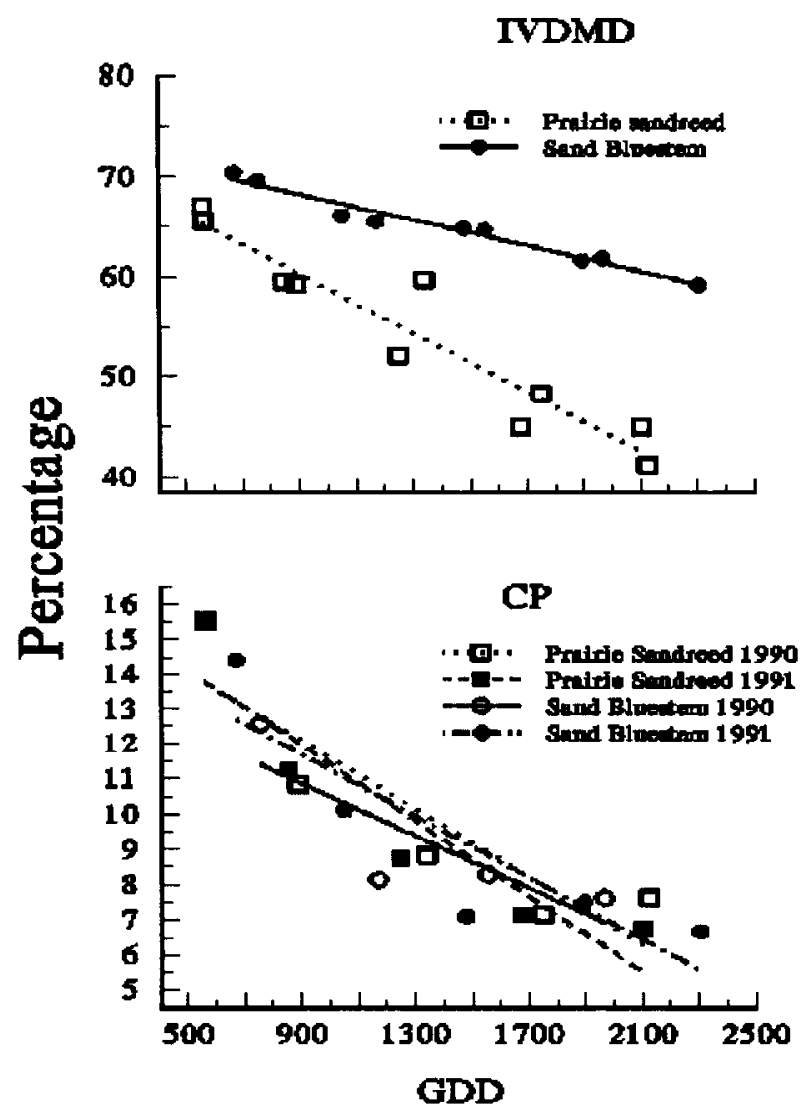

Fig. 4. In vitro dry matter digestibility (IVDMD) and crude protein (CP) correlated with growing degree days (GDD) for a single vegetative stage (V3) of prairie sandreed and sand bluestem in 1990 and 1991. The coefficients of variation (C.V.) are as follows; prairie sandreed IVDMD C.V. $=4.63$, sand bluestem IVDMD C.V. $=2.88$, prairie sandreed CP 1990 C.V. $=10.78,1991$ C.V. $=5.46$, sand bluestem CP 1990 C.V. $=6.17,1991$ C.V. $=10.28$.

The point where leaf $\mathrm{CP}$ values stabilized after the initial sharp decline was on the same day of the year for prairie sandreed and only 1 day apart in sand bluestem for both years (Fig. 3). The consistency of this relationship indicated that the stabilization of leaf $\mathrm{CP}$ may be related to photoperiod but this relationship appears to be largely unexplored. Initiation of stem elongation may stabilize leaf number which would minimize the effect of dilution on leaf $\mathrm{CP}$. However, the exact beginning of stem elongation could not be determined. The date that the first palpable node was detected in both species was 2 weeks earlier in 1991 than in 1990 but palpable nodes are an indicator of elongation rate rather than the initial starting point.

\section{Nutritive Value of V3 Tillers}

Nutritive value of tillers in the 3-leaf vegetative substage (V3) were correlated with day of the year and growing degree days. Based on the similarity of results only responses for growing degree days are shown (Fig. 4). Nutritive value for V3 tillers was similar to those of leaves in the entire tiller populations of both species. The IVDMD within a species between years was similar so the data were combined. Reductions in IVDMD in V3 tillers were similar to the leaves of the entire tiller population (Fig. 4). This further supports the interpretation that leaf aging affects leaf IVDMD more than morphological development. The declines in $\mathrm{CP}$ in the V3 samples were highly correlated with growing degree days and day of the year (Table 2). The decline of $\mathrm{CP}$ in the V3 stage was less rapid than for the leaves of the entire tiller population. Leaf aging in $\mathrm{V} 3$ tillers could he a mechanism associated with declines in leaf $\mathrm{CP}$, similar to other $\mathrm{C}_{4}$ grasses (Anderson 1985, Perry and Baltensperger 1979). Evaluating a single morphological stage would diminish the influence of the oldest leaves on CP early in the season, causing the CP of the V3 tillers to decline slower than the leaves of the tiller population.

\section{Conclusions}

The dominance of sand bluestem and prairie sandreed in the Nebraska Sandlills make their nutritive value important for ranchers. Our data indicated that decreases in cell wall digestibility, rather than reductions in the cell soluble fraction, was the major factor associated with the reduction in leaf IVDMD. Tissue aging was a major mechanism associated with reduction of leaf IVDMD in both species. Leaf $\mathrm{CP}$ was affected more by year than by species. Leaf $\mathrm{CP}$ declined sharply early in the growing season and then leveled out abruptly in early July, when mean stage by count rar ged from 1.3 to 1.6 and the plants had accumulated 1000 to 300 growing degree days. Since protein levels after early July were below requirements for average sized lactating cows (Taylor 1984, p. 318), producers may need to supplement lactating cows on pastures dominated by these 2 grasses.

\section{Literature Cited}

Äman, Per and Erik Lindgren. 1983. Chemical composition and in vitro degradability of individual chemical constituents of six Swedish grasses harvested at different stages of maturity. Swed. J. Agr. Res. 13:221-227.

Anderson, B. 1985. The influence of aging on forage quality of individual switchgrass leaves and stems. p. 947-949. In: Proc. of the 15th Int. Grassl. Congr., Kyoto, Japan. The National Grassland Research Institute, Nishi-nasuno, Tochigi-ken, 329--27, Japan.

A.O.A.C. 1976. Crude protein, Changes in official methods of analysis made at the 89th annual meeting. 13-16 Oct. 1975, J. Assoc. Official Anal. Chem. 59:459.

Burzlaff, D.F. 1971. Seasonal variations of the in vitro digestibility of three Sandhill grasses. J. Range Manage. 24:60-63.

Buxton, D.R. and G.C. Marten. 1989. Forage quality of plant parts of perennial grasses and relationship to phenology. Crop Sci. 29:429-435.

Goering, H.K. and P.J. Van Soest. 1970. Forage fiber analysis (Apparatus, reagents, procedures and some applications). USDA Agr. Handbook 379, Washington, D.C.

Griffin, J.L. and G.A. Jung. 1983. Leaf and stem forage quality of big bluestem and switchgrass. Agron. J. 75:951-956.

Heckathorn, S.A. and E.H. DeLucia. 1994. Drought-induced nitrogen retranslocation in perennial $\mathrm{C}_{4}$ grasses of tallgrass prairie. Ecol. 75:1877-1886.

Henderson, M.S. and D.L. Robinson. 1982a. Environmental influences on fiber component concentrations of warm-season perennial grasses. Agron. J. 74:573-579. 
Henderson, M.S. and D.L. Robinson. 1982b. Environmental influences on yield and in vitro true digestibility of warm-season perennial grasses and the relationships to fiber components. Agron. J. 74: 943-946.

Jonasson, S. and F.S. Chapin, III. 1985. Significance of sequential leaf development for nutrient balance of the cotton sedge, Eriophorum vaginatum $\mathrm{L}$. Oecologia 67:511-518.

Jung, H.C. 1989. Forage lignins and their effects on fiber digestibility. $\Lambda$ gron. J. 81:33-38.

Kirby, D.R. and J.W. Stuth. 1982. Seasonal diurnal variation in composition of cow diets. J. Range Manage. 35:7-8.

Marten, G.C. and R.F. Barnes. 1980. Prediction of energy digestibility of forages with in vitro rumen fermentation and fungal enzyme systems. p.61-71. In: W.J. Pigden, C.C. Balch, and M. Graham (eds.) Standardization of analytical methodology for feeds. Int. Div. Res. Ctr., Ottawa, Canada.

McKendrick, J.D., C.E. Owensby, and R.M. Hyde. 1975. Big bluestem and indiangrass vegetative reproduction and annual reserve carbohydrate and nitrogen cycles. Agro-Ecosystems 2:75-93.

Minson, D.J. 1990. Forage in ruminant nutrition. $\Lambda$ cademic Press, Inc. New York, N.Y.

Moore, K.J., L.E. Moser, K.P. Vogel, S.S. Waller, B.E. Johnson, and J.F. Pedersen. 1991. Describing and quantifying growth stages of perennial forage grasses. Agron. J. 83:1073-1077.

Northup, B.K. 1993. Utilization of native forages of the Nebraska Sandhills by yearling cattle. Ph.D. Diss., University of Nebraska, Lincoln, Neb.

Pate, J.S. and C.A. Atkins. 1983. Xylem and phloem transport and the functional economy of carbon and nitrogen of a legume leaf. Plant Physiol. 71:835-840.

Perry, L.J., Jr. and D.D. Baltensperger. 1979. Leaf and stem yields and forage quality of three $\mathrm{N}$-fertilized warm-season grasses. Agron. J. $71: 355-358$
Sanderson, M.A. and W.F. Wedin. 1989. Phenological stage and herbage quility relationships in temperate grasses and legumes. Agron. J. 81:864-869.

SAS Institute Inc. 1985. SAS user's guide: Statistics, Version 5 Edition. SAS Institute Inc. Cary, N.C.

Simon, U. and B.H. Park. 1983. A descriptive scheme for stages of development in perennial forage grasses. p. 416-418. In: J.A. Smith and V.W. Hays (eds.), Proc. 14th Int. Grassl. Congr., Lexington, KY. Westview Press. Boulder, Colo.

Sims, P. L., R. K. Lang'at, and D. N. Hyder. 1973. Developmental morphology of blue grama and sand bluestem. J. Range Manage. 26: 340-344.

Stuth, J.W. 1991. Foraging bchavior. p. 65-84. In: R.K. Hcitschmidt and J.W. Stuth (eds.), Grazing management: An ecological perspective. Timber Press. Portland, Ore.

Taylor, R.E. 1984. Beef production and the beef indu.try: A Beef producer's perspective. Macmillan Publishing Company. New York, N.Y.

Undersander, D.J. and D.P. Hutchenson. 1984. Seasonal changes of range grasses on the Texas High Plains. P. 191-196. In: Proc. Am. Forage and Grassl. Conf., Houston, Tex., Amer. Forage and Grassl. Counc., Genrgetown, Tex.

Van Soest, P.J. 1982. Nutritional ecology of the ruminant. Comstock Publishing Associates. Cornell University Press. Ithaca and London.

Van Soest, P.J., D.R. Mertens, B. Denium. 1978. Preharvest factors influencing quality of conserved forage. J. Anim. Sci. 47:712-720.

Yoneyama, T. 1977. Nitrogen nutrition and growth of the rice plant I. Nitrogen circulation and protein turnover in rice seedlings. Soil Sci. Plant Nutr. 23:237-245.

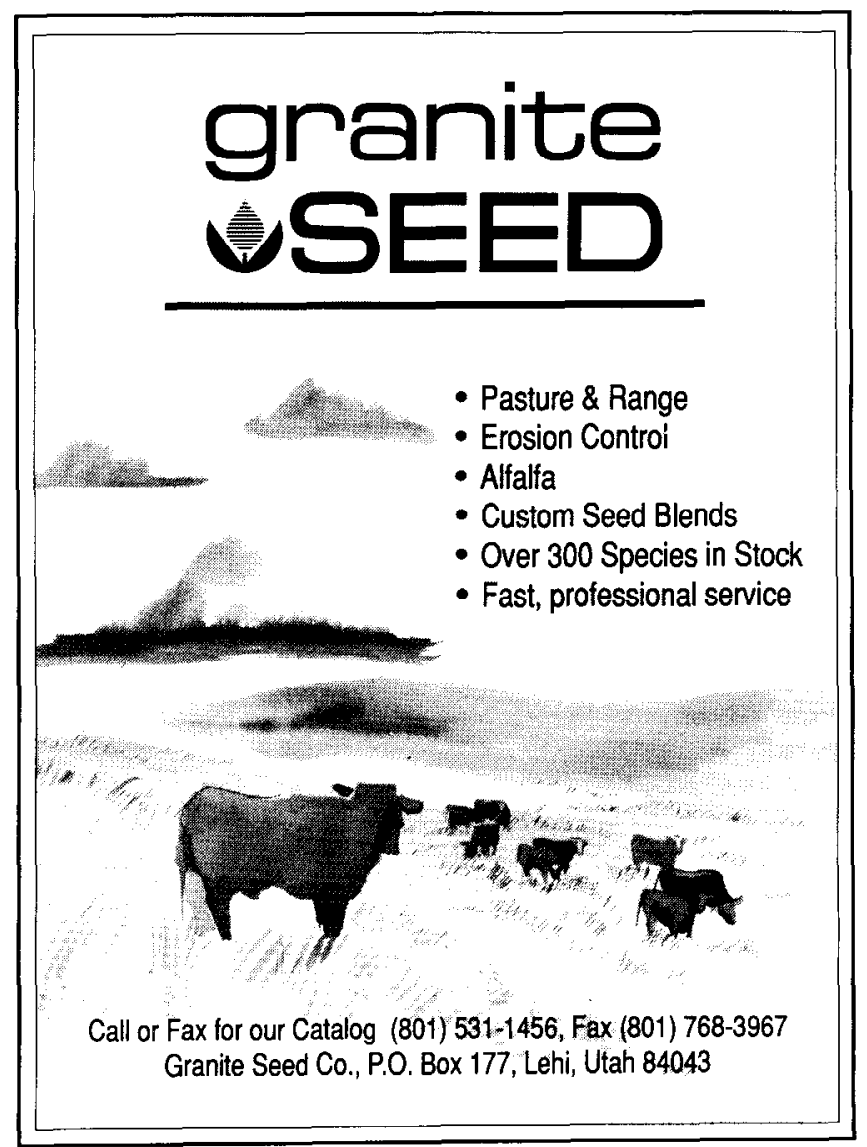

